Fitriah, Bentuk Dan Tanggungjawab Pihak Bank Terhadap Dana Simpanan Para Nasabah

Halaman 301-320

\title{
BENTUK DAN TANGGUNGJAWAB PIHAK BANK TERHADAP DANA SIMPANAN PARA NASABAH
}

\author{
Fitriah \\ Fakultas Hukum Universitas Palembang \\ Fitriah241171@yahoo.com
}

\begin{abstract}
A bank is a financial institution whose existence depends absolutely on the trust of its customers who entrust their savings funds. Banks are very concerned that the trust of the public, who have and who will save their funds, are well-maintained, considering that the bank is part of the financial system and payment system. Bank secrecy is very important because banks need the trust of the people who keep their money in the bank. The customer only entrusts his money to the bank or makes use of the bank's services if the bank provides a guarantee that the bank's knowledge of deposits and the state of their assets will not be misused. The legal relationship between the bank and the depository customer starts from the signing of a written agreement (contractual relationship) between the bank and the customer which contains the rights and obligations for each party. As for the form of agreement for depositing funds between the customer and the bank, it is called a deposit agreement (Article 1319 Civil Code). In a deposit agreement, the bank sets certain general requirements in a deposit account or savings account, among others, the recipient of the deposit (bank) can use the depositors' money and at a certain time the bank will provide interest. Other provisions that can be used as the basis of relations between banks and depositors are Proxy Giving. Depositors give their power to banks when signing deposit accounts or savings accounts or bank accounts. This agreement becomes a law or law for both parties (Article 1338 of the Civil Code). As a manifestation of the bank's responsibility for depositing customers, banks must pay attention to the 4 (four) pillars of the relationship between depositors and banks, namely: Prudence, Health, Bank Secrets and Trust.
\end{abstract}

\section{Keywords: Bank Secrets; Responsible; Customer}

\section{ABSTRACT}

Bank adalah suatu lembaga keuangan yang eksistensinya tergantung mutlak pada kepercayaan dari para nasabahnya yang mempercayakan dana simpanannya. Bank sangat berkepentingan agar kepercayaan masyarakat, yang telah maupun yang akan menyimpan dananya, terpelihra dengan baik, mengingat bank adalah bagian dari system keuangan dan system pembayaran. Kerahasian bank sangat penting karena bank memerlukan kepercayaan dari masyarakat yang menyimpan uangnya di bank. Nasabah hanya mempercayakan uangnya kepada bank atau memanfaatkan jasa bank apabila bank memberikan jaminan bahwa pengetahuan bank tentang simpanan dan keadaan keuangangannya tidak akan disalahgunakan. Hubungan hukum antara bank dengan nasabah penyimpan mulai sejak ditandatanganinya kesepakatan tertulis (hubungan kontraktual) antara bank dengan nasabah yang memuat hak dan kewajiban bagi masing-masing pihak. Adapun bentuk perjanjian penyimpanan dana antara nasabah dan pihak bank disebut perjanjian simpanan ( Pasal 1319 KUH perdata). Dalam perjanjian simpanan, pihak bank menetapkan persyaratan umum tertentu dalam rekening deposito atau rekening tabungan antara lain pihak penerima simpanan (bank) dapat mempergunakan uang si penyimpan dan dalam waktu tertentu bank akan memberikan bunga. Ketentuan lain yang dapat dijadikan dasar hubungan anatara bank dan nasabah penyimpan adalah Pemberian Kuasa. Nasabah penyimpan memberikan kuasanya kepada bank ketika menandatangani rekening deposito atau rekening tabungan atau rekening Koran. Perjanjian inilah yang menjadi hukum atau undang-undang bagi kedua belah pihak (Pasal $1338 \mathrm{KUH}$ Perdata). Sebagai wujud pertanggungjawaban bank terhadap nasabah penyimpan dana, bank harus memperhatikan 4 (empat) pilar hubungan antara nasabah penyimpan dana dan bank, yaitu : Kehatihatian, Kesehatan, Rahasia bank dan Kepercayaan.

Kata Kunci : Rahasia Bank; Tanggungjhawab; Nasabah 


\section{PENDAHULUAN}

\section{A. Latar Belakang}

Lembaga perbankan sebagai salah satu lembaga keuangan yang mempunyai nilai strategis dalam kehidupan perekonomian suatu negara. Penghimpunan dana merupakan jasa utama yang ditawarkan dalam dunia perbankan. Dana yang di himpun dari masyarakat merupakan suatu tulang punggung dari dana yang dikelola oleh bank untuk memperoleh keuntungan.

Bank adalah bagian dari sistem keuangan dan sistem pembayaran suatu Negara, bahkan pada era globalisasi sekarang ini, bank juga telah menjadi bagian dari sistem keuangan dan sistem pembayaran dunia. Bank yang telah memperoleh izin berdiri dan beroperasi dari otoritas moneter dari negara yang bersangkutan, bank tersebut menjadi milik masyarakat. Eksistensinya bukan saja harus di jaga oleh para pemilik bank itu sendiri dan pengurusnya, tetapi juga oleh masyarakat nasional dan global.

Bank dalam melaksanakan kemintraan antara bank dengan nasabahnya, kegiatan bank harus dilandasi oleh prinsip-prinsip hukum perbankan untuk menciptakan system perbankan yang sehat, yaitu : prinsip demokrasi ekonomi, prinsip kepercayaan, prinsip kehati-hatian, dan prinsip kerahasiaan.

Bank adalah suatu lembaga keuangan yang eksistensinya tergantung mutlak pada kepercayaan dari para nasabahnya yang mempercayakan dana simpanan mereka pada bank. Bank sangat berkepentingan agar kadar kepercayaan masyarakat, yang telah maupun yang akan menyimpan dananya, terpelihra dengan baik dalam tingkat yang tinggi, mengingat bank adalah bagian dari system keuangan dan system pembayaran, masyarakat luas berkepentingan atas kesehatan dari sistemsistem tersebut, sedangkan kepercayaan masyarakat kepada bank merupakan unsur pokok dari eksistensi suatu bank, maka terpeliharanya kepercayaan masyarakat kepada perbankan adalah juga kepentingan masyarakat banyak.

Kerahasian bank sangat penting karena bank memerlukan kepercayaan dari masyarakat yang menyimpan uangnya di bank. Nasabah hanya mempercayakan uangnya kepada bank atau memanfaatkan jasa bank apabila bank memberikan jaminan bahwa pengetahuan bank tentang simpanan dan keadaan keuangangannya tidak akan disalahgunakan. Adanya jaminan kerahasian bank atas semua datadata masyarakat dalam hubungannya dengan bank, masyarakat akan mempercayainya bank tersebut, selanjutnya mereka akan mempercayakan uangnya pada bank atau memanfaatkan jasa bank.

Hubungan hukum antara bank dengan nasabah penyimpan mulai sejak ditandatanganinya kesepakatan tertulis (hubungan kontraktual) antara bank dengan nasabah yang memuat hak dan kewajiban bagi masing-masing pihak. Namun hal yang sering terjadi saat nasabah penyimpan dana bertransaksi dengan pihak bank adalah kebanyakan nasabah tidak mengetahui isi perjanjian yang mereka tanda tangani. Perjanjian yang seharusnya di buat berdasarkan kesepakatan antar kedua belah pihak sepertinya tidak berlaku karena pihak bank dengan alasan efisiensi telah mempersiapkan klausul baku perjanjian yang tinggal disodorkan dan ditandatangani oleh nasbah dan sering kali dicetak dalam bentuk yang sangat kecil dan terkesan rumit untuk di baca. Padahal isi atau klausul kontrak pada perjanjian perbankan saat menentukan hak dan kewajiban yang akan diperoleh dalam melakukan transaksi pada sebuah produk perbankan. 
Pengertian Bank menururt menurut Undang-Undang RI Nomor 10 Tahun 1998 (Pasal 1) tentang Perbankan menyebutkan bahwa Bank adalah badan usaha yang menghimpun dana dari masyarakat dalam bentuk simpanan dan menyalurkannya kepada masyarakat dalam bentuk kredit dan atau bentuk-bentuk lainnya dalam rangka meningkatkan taraf hidup rakyat banyak.

Sedangkan menurut Hasibuan, pengertian bank adalah: Bank adalah badan usaha yang kekayaannya terutama dalam bentuk aset keuangan (financial assets) serta bermotif profit juga sosial, jadi bukan hanya mencari keuntungansaja. ${ }^{1}$

Selain itu bank merupakan lembaga keuangan yang kegiatannya menghimpun dana dari masyarakat dalam bentuk simpanan kemudian menyalurkan kembali ke masyarakat, serta memberikan jasa-jasa bank lainnya. $^{2}$

Berdasarkan ketiga pengertian di atas dapat disimpulkan bahwa bank adalah usaha yang berbentuk lembaga keuangan yang menghimpun dana dari masyarakat yang memiliki kelebihan dana (surplus of fund) dan menyalurkannya kembali kepada masyarakat yang kekurangan dana (lack of fund), serta memberikan jasa-jasa bank lainnya untuk motif profit juga sosial demi meningkatkan taraf hidup rakyat banyak.

$$
\text { Adapun Pasal } 5 \text { Undang- }
$$

undang Nomor 10 Tahun 1998 tentang Perbankan,dikatakan menurut jenisnya bank terdri atas :

1. Bank Umum

Bank Umum adalah Bank yang melaksanakan kegiatan usaha secara konvensional dan /atau berdasarkan prinsip syairiah yang dalam kegiatannya

\footnotetext{
Hasibuan, Melayu SP. Dasar-dasar Perbankan.Jakarta: PT. Bumi Aksara. 2005, hal.2

${ }^{2}$ Kasmir. S.E., M.M,. Dasar-Dasar Perbankan. Jakarta: PT. Raja Grafindo Persada ,2002, hal 2
}

memberikan jasa dalam lalu lintas pembayaran.

2. Bank Perkreditan Rakyat

Bank Perkreditan Rakyat adalah Bank yang melaksanakan kegiatan usaha secara konvensional tidak memberikan jasa dalam lalu lintas pembayaran.

Sesuai dengan Pasal 6 Undang-undang Nomor 10 tahun 1998, tentang perbankan, maka usaha-usaha yang dapat dilakukan bank meliputi :

1. Menghimpun dana dari masyarakat dalam bentuk simpanan berupa giro, deposito berjangka, sertifikat deposito, tabungan dan/atau bentuk lainnya yang dipersamakan dengan itu;

2. Memberikan Kredit;

3. Memberikan Surat pengakuan hutang ;

4. Membeli, menjual atau menjamin atas resiko sendiri maupun untuk kepentingan dan atas perintah nasabahnya;

a. Surat-surat wesel termasuk wesel yang diakseptasi oleh bank yang masa berlakunya tidak lebih lama daripada kebiasaan dalam perdagangan surat-surat dimaksud.

b. Surat pengakuan hutang dan kertas dagang lainnya yang masa berlakunya tidak lebih lama dalam perdagangan surat-surat dimaksud.

c. Kertas perbendaharaan negara dan surat jaminan pemerintah.

d. Sertifikat Bank Indonesia

e. Obligasi

f. Surat dagang berjangka wakru sampai dengan 1 (satu) tahun 
g. Instrumen surat berharga lain yang berjangka waktu sampai 1 (satu) tahun.

5. Memindahkan uang baik untuk kepentingan sendiri maupun untuk kepentingan nasabah

6. Menempatkan dana pada, meminjam dana dari atau meminjamkan dana kepada bank lain, baik dengan menggunakan surat, sarana telekomunikasi maupun dengan wesel unjuk, cek atau sarana lainnya.

7. Menerima pembayaran dari tagihan atas surat berharga dan melakukan perhitungan dengan antar pihak ketiga.

8. Menyediakan tempat untuk menyimpan barang dan surat berharga.

9. Melakukan kegiatan penitipan untuk kepentingan pihak lain berdasarkan kontrak.

10. Melakukan penempatan dana dari nasabah kepada nasabah lainnya dalam bentuk surta berharga yang tidak tercatat di bursa efek.

11. Melakukan kegiatan anjak piutang, usaha kartu kredit dan wali amanat.

12. Menyediakan pembiayaan dan atau melakukan kegiatan lain berdasarkan prinsip syariah, sesuai dengan ketentuan yang ditetapkan oleh Bank Indonesia.

13. Melakukan kegiatan lain yang lazim dilakukan oleh bank sepanjang tidak bertentangan dengan UU ini dan Peraturan Perundang-undangan yang berlaku.

Oleh karena itu penulis akan menuangkan dalam bentuk tulisan yang berjudul : “ Bentuk Dan Tanggungjawab Pihak Bank Terhadap Dana Simpanan Para Nasabah".

\section{B. Permasalahan}

Berdasarkan latar belakang di atas maka permasalahan yang akan diteliti adalah : Bagaimanakah bentuk tanggungjawab pihak bank terhadap dana simpanan para nasabahnya?

\section{Metode Penelitian}

Dalam penelitian ini jenis penelitian yang digunakan adalah jenis penelitian yuridis normative, yaitu penelitian yang dilakukan pada peraturan-peraturan yang tertulis yang berkaitan dengan masalah bentuk tanggungjawab pihak bank terhadap dana simpanan para nasabahnya .

\section{PEMBAHASAN}

Demokrasi ekonomi dengan asas dasar aktivitas kegiatan perekonomian yang mempunyai arti bahwa masyarakat harus memegang peranan aktif dalam kegiatan perbankan, tapi juga pemerintah berkewajiban untuk memberi pengarahan dan bimbingan terhadap pertumbuhan ekonomi serta menciptakan iklim yang sehat bagi perkembangan dunia usaha. Jadi fungsi perbankan adalah sebagai penghimpun dana dan menyalurkan dana tersebut ke masyarakay, oleh karena itu setiap lembaga perbankan selalu berusaha menarik dana masyakarakt sebanyak mungkin dengan memberikan imbalan berupa bunga dan adakalanya bank memberikan hadiah-hadiah.

Sedangakan fungsi perbankan yang lebih spesifik lagi yaitu sebagai : ${ }^{3}$

1. Agent of Trust

Dasar utama kegiatan perbankan adalah kepercayaan (trust), baik dalam hal menghimpun dana maupun penyaluran dana. Masyarakat mau menitipkan dananya di bank apabila dilandasi adanya unsur kepercayaan. Masyarakat percaya bahwa uangnya tidak akan disalahgunakan oleh bank,

3. Budisantoso, $\mathrm{T}$ dan Sigit,. Bank dan Lembaga Keuangan Lain. Edisi 2. Jakarta: Salemba Empat.2006,hal.9 
uangnya akan dikelola dengan baik, bank tidak akan bangkrut, dan pada saat yang telah dijanjikan simpanan tersebut dapat ditarik kembali dari bank. Pihak bank sendiri akan mau menempatkan atau menyalurkan dananya pada debitur atau masyarakat apabila dilandasi adanya unsur kepercayaan. Pihak bank percaya bahwa debitur tidak akan menyalahgunakan pinjamannya, debitur akan mengelola dana pinjaman saat jatuh tempo, dan debitur mempunyai niat baik untuk mengembalikan pinjaman beserta kewajiban lainnya pada saat jatuh tempo.

\section{Agent of Development}

Kegiatan perekonomian masyarakat di sektor moneter dan di sektor riil tidak dapat dipisahkan. Kedua sektor tersebut selalu berinteraksi dan saling mempengaruhi. Sektor riil tidak akan dapat berkinerja dengan baik apabila sektor moneter tidak bekerja dengan baik. Kegiatan bank berupa penghimpunan dan penyaluran dana sangat diperlukan bagi lancarnya kegiatan perekonomian di sektor riil. Kegiatan bank tersebut memungkinkan masyarakat melakukan kegiatan investasi, kegiatan distribusi, serta kegiatan konsumsi barang dan jasa, mengingat bahwa kegiatan investasi-distribusikonsumsi tidak dapat dilepaskan dari adanya penggunaan uang. Kelancaran kegiatan investasi, distribusi, dan konsumsi ini tidak lain adalah kegiatan pembangunan perekonomian suatu masyarakat.

3. Agent of Service
Di samping melakukan kegiatan penghimpunan dan penyaluran dana, bank juga memberikan penawaran jasa perbankan yang lain kepada masyarakat. Jasa ditawarkan bank ini erat kaitannya dengan kegiatan perekonomian secara luas. Jasa ini antara lain dapat berupa jasa pengiriman uang, penitipan barang berharga, pemberian jaminan bank, dan penyelesaian tagihan.

Jadi jelaslah bahwa tujuan dari perbankan Indonesia adalah menunjang pelaksanaan pembangunan nasional dalam rangka meningkatkan pemerataan pertumbuhan ekonomi, dan stabilistas nasioanal ke arah peningkatan kesejahteraan rakyat banyak. Nasabah merupakan pihak yang menggunakan jasa bank. Penghimpunan dana dan pemberian kredit merupakan pelayanan jasa perbankan yang utama dari semua kegiatan lembaga keuangan bank.Berdasarkan Pasal 1 angka (16) UU Perbankan diintroduksikan rumusan nasabah yaitu nasabah adalah pihak yang menggunakan jasa bank. Rumusan tersebut kemudian diperinci pada butir berikutnya yaitu sebagai berikut:

1. Nasabah Penyimpan adalah nasabah yang menempatkan dananya di bank dalam bentuk simpanan berdasarkan perjanjian bank dengan nasabah yang bersangkutan.

2. .Nasabah Debitur adalah nasabah yang memperoleh fasilitas kredit atau pembiayaan berdasarkan Prinsip Syariah atau yang dipersamakan dengan itu berdasarkan perjanjian bank dengan nasabah yang bersangkutan. 
Di dalam praktik -praktik perbankan, dikenal 3 (tiga) macam nasabah antara lain:

1. Nasabah deposan, yaitu nasabah yang menyimpan dananya disuatu bank, misalnya dalam bentuk deposito atau tabungan;

2. Nasabah yang memanfaatkan fasilitas kredit perbankan, misalnya kredit usaha kecil, kredit pemilikan rumah dan sebagainnya;14Pasal 1 ayat (17) Undang-Undang Nomor 10 Tahun 1998 tentang Perubahan atas UndangUndang Nomor 7 Tahun 1992 tentang Perbankan.15Pasal 1ayat (18) Undang-Undang Nomor 10 Tahun 1998 tentang Perubahan atas Undang-Undang Nomor 7 Tahun 1992 tentang Perbankan.

3. Nasabah yang melakukan transaksi dengan pihak lain melalui bank, misalnya, transaksi antara importir sebagai pembeli dan eksportir di luar negeri. Untuk transaksi semacam ini, biasanya importir membuka letter of credit(L/C) pada suatu bank demi kelancaran dan keamanan pembayaran.

Lembaga Penjamin Simapanan (selanjutnya disingkat LPS) adalah lembaga yang independen, transparan, dan akuntabel dalam melaksanakan tugas dan wewenangnya. Penjaminan simpanan nasabah bank yang diharapkan dapat memelihara kepercayaan masyarakat terhadap industri perbankan dan dapat meminimumkan risiko yang membebani anggaran Negara. LPS mempunyai fungsi yang sangat penting, yaitu menjamin simpanan nasabah penyimpan serta turut aktif dalam memelihara stabilitas sistem perbankan sesuai dengan kewenangannya. Dalam memelihara stabilitas sistem perbankan sesuai dengan kewenangannya, LPS akan melakukan penyelesaian atau penanganan bank gagal.

Bank gagal (failing bank) adalah bank yang mengalami kesulitan keuangan dan membahayakan kelangsungan usahanya serta dinyatakan tidak dapat disehatkanoleh Lembaga Pengawas Perbankan (selanjutnya disingkat LPP) sesuai dengan kewenangan yang dimilikinya. LPP adalah Bank Indonesia atau lembaga pengawas sektor jasa keuangan sebagaimana dimaksud dalam Undang-Undang tentang Bank Indonesia. Apabila kondisi bank yang mengalami kesulitan keuangan tersebut semakin memburuk, antara lain ditandai dengan menurunnya tingkat solvabilitas bank, tindakan penyelesaian dan penyehatan lain harus segera dilakukan.

Dalam menjalankan fungsinya, LPS mempuyai tugas-tugas yang meliputi:

1. Merumuskan dan menetapkan kebijakan pelaksanaan penjaminan simpanan;

2. Merumuskan dan menetapkan kebijakan dalam rangka turut aktif memelihara stabilitas sistem perbankan sesuai dengan kewenangannya;

3. Melaksanakan penjaminan simpanan;

4. Merumuskan, menetapkan, dan melaksanakan kebijakan penyelesaian bank gagal (bank resolution) yang tidak berdampak sistematik; dan

5. Melaksanakan penaganan bank gagal yang berdampak sistematik.

Sedangkan dalam rangka melaksakan tugas LPS mempunyai wewenang sebagai berikut:

1. Menetapkan dan memungut premi penjaminan; 
2. Menetapakan dan memungut kontribusi pada saat bank pertama kali menjadi peserta;

3. Melakukan pengelolaan kekayaan dan kewajiban LPS mendapatkan data simpanan nasabah, data kesehatan bank, laporan keuangan bank, dan laporan hasil pemeriksaan bank sepanjang tidak melanggar kerahasiaan bank; dan

4. Menetapkan syarat, tata cara, dan ketentuan pembayaran klaim;

5. Menunjuk, menguasakan, dan atau menugaskan pihak lainuntuk bertindak bagi kepentingan dan atau atas nama LPS, guna melaksanakan sebagai tugas tertentu;

6. Melakukan penyuluhan kepada bank dan masyarakat tentang penjaminan simpanan; dan

7. Menjatuhkan sanksi administratif.Terhadap penyelesaian dan penanganan bank gagal LPS mempunyai kewenangan, yaitu:

a.mengambil alih dan menjalankan segala hak dan wewenang pemegang saham termasuk hak dan wewenang Rapat Umum Pemegang Saham (RUPS);

b.menguasai dan mengelola aset dan kewajiban bank gagal yang diselamatkan;

c.meninjau ulang, membatalkan, mengakhiri dan/atau mengubah setiap kontrak yang mengikat bank gagal yang diselamatkan dengan pihak ketiga yang

merugikan bank; dan

d.menjual dan/atau mengembalikan aset bank tanpa persetujuan debitur dan/atau kewajiban bank tanpa persetujuan kreditur.

Pada dasarnya bank

menjalankan prinsip kepercayaan yang diberikan oleh penyimpan dana untuk menjaga kerahasiaan rekening nasabahnya. Oleh karena hubungan bank dan nasabah adalah bersifat kerahasiaan, hal ini sering disebut dengan rahasia bank (bank secrecy). Istilah rahasia bank ini mengacu kepada hal-hal yang berhubungan dengan interaksi antara bank dengan nasabahnya. Nasabah tentu tidak mengharapkan untuk memberitahu pihak ketiga tentang keadaan keuangan nasabah tersebut.

Rahasia Bank atau Banking Secrecy dikenal di negara manapun di dunia ini yang mempunyai lembaga keuangan bank. Rahasia bank tidak bedanya dengan rahasia yang harus dipegang teguh oleh para professional seperti pengacara yang wajib merahasiakan hal-hal yang menyangkut penyakit pasiennya. Bahkan kalau rahasia dimaksud tidak dipegang teguh dan dibocorkan kepada pihak lain, maka atas tindakan tersebut dapat dikenakan sanksi, baik perdata maupun pidana.

Kerahasiaan informasi yang lahir dalam kegiatan perbankan ini pada dasarnya lebih banyak untuk kepentingan bank itu sendiri, karena sebagai lembaga keuangan, kepercayaan adalah keutamaan dalam melaksanakan kegiatannya. Untuk menjamin hal itu, pemerintah telah menjamin hak-hak nasabah dengan undang-undang, yaitu Undang-Undang Perbankan. Hubungan antara bank dengan nasabah ternyata tidaklah seperti hubungan kontraktual biasa. Akan tetapi dalam hubungan tersebut terdapat pula kewajiban bagi bank untuk tidak membuka rahasia nasabahnya kepada pihak lain manapun kecuali jika ditentukan lain oleh perundang - undangan yang berlaku. Hal ini dinamakan rahasia bank. Dengan demikian, istilah rahasia bank mengacu pada rahasia dalam hubungan antara bank dengan nasabahnya.

Kegiatan dunia perbankan mengelola uang masyarakat, maka bank wajib menjaga kepercayaan yang diberikan masyarakat. Bank wajib menjaga 
keamanan uang tersebut agar benar - benar aman, agar keamanan uang nasabahnya terjamin, pihak perbankan dilarang untuk memberikan keterangan yang tercatat pada bank tentang keadaan keuangan dan halhal lain dari nasabahnya. Dengan kata lain bank harus menjaga rahasia tentang keadaan keuangan nasabah dan apabila melanggar kerahasiaan ini perbankan akan dikenakan sanksi. Untuk dapat memelihara dan meningkatkan kepercayaan masyarakat terhadap suatu bank pada khususnya dan perbankan pada umumnya adalah dapat tidaknya bank dipercaya oleh nasabah yang menyimpan dananya dan atau menggunakan jasa-jasa lainnya dari bank tersebut untuk tidak mengungkapkan keadaan keuangan dan transaksi nasabah serta keadaan lain dari nasabah yang bersangkutan kepada pihak lain. Dalam hal ini prinsip kerahasiaan bank sangat penting dalam menjaga kepercayaan masyarakat.

Rahasia bank adalah segala sesuatu yang berhubungan dengan keuangan dan hal- hal lain dari nasabah bank yang menurut kelaziman dunia perbankan tidak boleh secara terbuka diungkapkan kepada pihak masyarakat. Dalam hubungan ini yang menurut kelaziman wajib dirahasiakan oleh bank, adalah seluruh data dan informasi mengenai segala sesuatu yang berhubungan dengan keuangan, dan halhal lain dari orang, dan badan yang diketahui oleh bank karena kegiatan usahanya. Dalam rangka untuk menghindari kemungkinan terjadinya kekurangpercayaan masyarakat terhadap dunia perbankan, yang pada saat ini tengah gencar melakukan ekspansi untuk mencari dan menjaring nasabah, maka perlindungan hukum bagi nasabah penyimpan terhadap kemungkinan terjadinya kerugian sangat diperlukan.

Pada mulanya Bank muncul dan berkembang dari kegiatan tukarmenukar yang dikenal sejak zaman purbakala di Athena, dan Romawi. Pada zaman itu, di Athena orang yang menjalankan tugas tukar-menukar uang dinamakan trapezites (orang dihadapan meja) atau argentarius di Romawi. Selain melakukan tugas tukar-menukar uang mereka juga menjalankan tugas menyimpan serta meminjamkan uang bagi mereka yang memerlukan. Usaha tukarmenukar dan simpan-pinjam ini menjadi lebih berkembang pada akhir abad pertengahan. Hal ini disebabkan karena perkembangan usaha-usaha perdagangan di Eropa serta timbulnya berbagai mata uang yang dimiliki oleh beberapa negara. Khusus dalam tugas peminjaman uang dilakukan oleh orang-orang Yahudi, kemudian diikuti oleh orang-orang Italia yang berasal dari Lombardia.

Sejak 4000 tahun yang lalu di Babylonia, kerahasiaan bank sebagai suatu kelaziman telah dipraktekkan sebagaimana tercantum dalam Code of Hamourabi. Begitu juga pada Kerajaan Romawi Kuno, hal yang menyangkut hubungan antara nasabah dan perbankan sudah diatur, termasuk di dalamnya kerahasiaan bank. Sejarah mencatat pula aturan tentang pelarangan-pelarangan yang berkaitan tentang bank termaktum dalam ketentuan Banco Ambrosiano di Milano-Italia pada tahun 1593. Bank-bank yang melanggar ketentuan rahasia bank, ijin usahanya dapat dicabut

Konsep rahasia bank bermula timbul dari tujuan untuk melindungi nasabah bank yang bersangkutan. Hal ini nyata terlihat ketika Court of Appeal Inggris secara bulat memutuskan pendiriannya dalam kasus Tournier $\mathrm{v}$. National Provincial and Union Bank of England tahun 1924, suatu putusan pengadilan yang kemudian menjadi leading case law yang menyangkut ketentuan rahasia bank di Inggris dan kemudian diacu oleh pengadilanpengadilan negara-negara lain yang menganut common law system. Bahkan 60 tahun sebelum putusan Tournier tersebut, 
yaitu dalam perkara Foster v. The Bank of London tahun 1862, juri telah berpendapat bahwa terdapat kewajiban bagi bank untuk tidak boleh mengungkapkan keadaan keuangan nasabah bank yang bersangkutan kepada pihak lain. Namun pada waktu itu pendirian tersebut belum memperoleh afirmasi dar putusan-putusan pengadilan berikutnya.

Timbulnya pemikiran untuk perlunya merahasiakan keadaan keuangan nasabah bank sehingga melahirkan ketentuan hukum mengenai kewajiban rahasia bank, adalah semula bertujuan untuk melindungi kepentingan nasabah secara individual. Ketentuan rahasia bank di Swiss, yaitu suatu negara yang dikenal mempunyai ketentuan rahasia bank yang dahulunya paling ketat di dunia, adalah juga semula bertujuan untuk melindungi kepentingan nasabah bank secara individual. Pada waktu itu ketentuan rahasia bank bersifat mutlak; artinya tidak dapat dikecualikan karena alasan apapun juga. Ketentuan rahasia bank di Swiss lahir mula-mula sehubungan dengan kedudukan Swiss sebagai negara yang netral secara tradisional. Alasan pertama, dalam abad ke-17, ribuan kaum Huguenots dari Perancis melarikan diri ke Swiss oleh karena mereka dikejar-kejar atau dilakukan penyiksaan-penyiksaan terhadap mereka sehubungan dengan agama yang mereka anut. Diantara mereka itu kemudian ada yang menjadi bankir, dan menginginkan agar supaya kerahasiaan dari nasabahnasabah mereka untuk urusan-urusan keuangannya di negara asalnya dirahasiakan. Alasan kedua adalah sehubungan dengan dikejar-kejarnya orang-orang Yahudi di waktu regime Nazi berkuasa di Jerman di tahun 1930-an dan 1940-an .

Namun perkembangan sehubungan dengan keadaan politik dalam negeri, keadaan sosial, terutama yang menyangkut timbulnya kejahatankejahatan di bidang money laundering, dan kebutuhan akan adanya stabilitas ekonomi, terutama stabilitas moneter, telah menimbulkan kebutuhan akan perlunya pelonggaran terhadap kewajiban rahasia bank yang mutlak itu. Artinya, apabila kepentingan negara, bangsa dan masyarakat umum harus didahulukan daripada kepentingan nasabah secara pribadi, maka kewajiban bank untuk melindungi kepentingan nasabah secara individual itu (dalam arti tidak boleh mengungkapkan keadaan keuangan nasabah) harus dapat dikesampingkan. Merupakan hal yang kontradiktif bahwa dalam hal-hal tertentu, justru demi kepentingan negara, bangsa dan masyarakat umum, dikehendaki agar kewajiban rahasia bank diperketat. Kepentingan negara yang dimaksud adalah pengerahan dana perbankan untuk keperluan pembangunan. Kepentingan negara, bangsa dan masyarakat umum itu dilandasi oleh alasan bahwa dijunjung tingginya dan dipegang teguhnya kewajiban rahasia bank merupakan faktor terpenting bagi keberhasilan bank dalam upaya bank itu mengerahkan tabungan masyarakat. Selain itu terganggunya stabilitas moneter adalah antara lain dapat diakibatkan oleh runtuhnya kepercayaan masyarakat terhadap perbankan karena terlalu longgarnya rahasia bank. Dalam kaitan itu, undang-undang yang mengatur mengenai rahasia bank harus tidak memungkinkan kewajiban rahasia bank secara mudah dapat dikesampingkan dengan dalih karena kepentingan umum menghendaki demikian Pasal 1131 KUHPerdata menjelaskan bahwa:"segala kebendaan si berutang, baik yang bergerak maupun yang tak bergerak, baik yang sudah ada maupun yang baru akan ada dikemudian hari, menjadi tanggungan untuk segala perikatan perseorangan".

Penjelasan di atas menyiratkan bahwa jaminan harus ada dalam hal suatu perikatan. Istilah jaminan dalam perspektif hukum perbankan dibedakan dengan 
istilah agunan. Arti jaminan yaitu keyakinan atas itikad dan kemampuan serta kesanggupan nasabah debitur untuk melunasi utangnya atau mengembalikan pembiayaan dimaksud sesuai dengan yang diperjanjikan. ${ }^{4}$ Istilah agunan sesuai Pasal 1 angka 23 Undang-Undang Nomor 10 Tahun 1998 tentang Perubahan Atas UndangUndang Nomor 7 Tahun 1992 tentang Perbankan yaitu jaminan tambahan yang diserahkan nasabah debitur kepada bank dalam rangka pemberian fasilitas kredit atau pembiayaan berdasarkan prinsip syariah. Jaminan Kredit adalah segala sesuatu yang mempunyai nilai mudah untuk dituangkan yang diikat dengan janji sebagai jaminan untuk pembayaran dari utang debitur berdasarkan perjanjian kredit yang dibuat kreditur dan debitur. $^{5}$

Jaminan ideal yang secara maksimal dapat menjamin bahwa kreditor dapat menerima kembali uang yang dipinjamkan harus memenuhi semua syarat sebagai berikut: ${ }^{6}$

a) Tidak menyusahkan debitur dalam melakukan usahanya, sehingga

memungkinkan debitur

membayar kembali utangnya,

b) Mudah diidentifikasi,

c) Setiap waktu tersedia untuk dieksekusi,

d) Nilai yang tidak mudah merosot,

e) Mudah direalisasikan sehingga kreditor dapat menerima dananya untuk

melunasi utangnya,

f) Mudah diketahui oleh pihak lain supaya tidak ada jaminan kedua dipasang

\footnotetext{
4 Rachmadi Usman, Hukum Jaminan Keperdataan. Jakarta: Sinar Grafika,2008, hal 67 Sutarno, Aspek-Aspek Hukum Perkreditan Pada Bank. Bandung : Alfabeta,2005, hal.142

${ }^{6}$ Ibid, hal.11
}

atas agunan yang sama kecuali dengan sepengetahuan atau persetujuan

pemegang jaminan,

g) Tidak mahal untuk membuatnya dan untuk merealisasikan.

Fungsi jaminan kredit baik ditinjau dari sisi bank maupun dari sisi debitur dapat dikemukakan sebagai berikut:

a) Jaminan Kredit sebagai Pengaman Pelunasan Kredit

Keterkaitan jaminan kredit dengan pengamanan kredit dapat disimpulkan

dari ketentuan Pasal 1131 KUHPerdata sehingga merupakan upaya lain

atau alternatif yang dapat digunakan bank untuk memperoleh perlunasan

kredit pada waktu debitur ingkar janji kepada bank.

b) Jaminan Kredit sebagai Pendorong Motivasi Debitur

Pengikatan jaminan kredit yang berupa harta milik debitur yang dilakukan oleh pihak bank, tentunya debitur yang bersangkutan takut akan kehilangan hartanya tersebut. Hal ini akan mendorong debitur berupaya untuk melunasi kreditnya kepada bank agar hartanya yang dijadikan jaminan kredit tersebut tidak kehilangan karena harus dicairkan oleh bank.

c) Fungsi yang Terkait dengan Pelaksanaan Ketentuan Perbankan

Keterkaitan jaminan kredit dengan ketentuan perbankan yang dikeluarkan oleh Bank Indonesia, misalnya dapat diperhatikan dari ketentuan-ketentuan yang mengatur tentang penilaian agunan sebagai faktor pengurang dalam perhitungan PPA (Penyisihan Penghapusan Aktiva). 
Persyaratan agunan untuk dilakukan dengan cara pemberian tambahan fasilitas kredit dalam rangka manajemen risiko kredit dan sebagainya.

Semua perjanjian pengikatan jaminan bersifat accesoir artinya perjanjian pengikatan jaminan eksistensinya atau keberadaannya tergantung perjanjian pokoknya yaitu perjanjian kredit, sehingga perjanjian kredit harus dibuat terlebih dahulu baru kemudian perjanjian pengikatan jaminan. Kedudukan perjanjian jaminan yang dikonstruksikan sebagai perjanjian accesoir mempunyai akibat hukum yaitu :

a) Eksistensinya tergantung perjanjian pokok (perjanjian kredit)

b) Hapusnya tergantung perjanjian pokok (perjanjian kredit)

c) Jika perjanjian pokok beralih maka ikut beralih juga perjanjian jaminan,

d) Jika perjanjian pokok beralih karena cessie, maka ikut beralih juga

perjanjian jaminan tanpa adanya penyerahan khusus.

Menurut R.Subekti, perjanjian adalah suatu peristiwa dimana seseorang berjanji kepada seseorang lain atau dimana dua orang itu saling berjanji untuk melaksanakan sesuatu hal. Dari peristiwa itu timbulah suatu hubungan antara dua orang yang dinamakan perikatan antara dua orang yang membuatnya. Dalam bentuknya perjanjian itu berupa suatu rangkaian kata-kata yang mengandung janji-janji atau kesanggupan yang diucapkan atau ditulis. ${ }^{7}$

Tentang perjanjian ini diatur dalam buku III KUHPerdata perihal hukum perikatan yang sistematikanya terbagi atas dua bagian, yaitu bagian umum dan khusus. Antara bagian umum

7 R.Subekti, Hukum Perjanjian, Jakarta: PT. Intermasa, 1985, hal.25 dan bagian khusus ini ada hubungannya satu sama lain, yaitu suatu hubungan dimana asas-asas bagian umum dari perikatan berlaku juga bagi perjanjian tertentu sebagaimana yang tercantum/diisyaratkan dalam Pasal 1320 KUHPerdata yang menentukan syaratsyarat sahnya suatu perjanjian. Dalam hukum perjanjian yang didasarkan pada KUHPerdata berlaku suatu asas yang dinamakan asas konsensualisme yang artinya bahwa perjanjian itu sudah sah dan mengikat apabila kedua belah pihak sudah sepakat mengenai hal yang pokok dan tidak diperlukan suatu formalitas. Asas konsensualisme yang terdapat dalam buku perjanjian lazimnya disimpulkan dalam Pasal 1320 KUHPerdata menyebutkan: ${ }^{8}$

a) Adanya kesepakatan

Sepakat berarti bahwa kedua belah pihak yang membuat perjanjian harus benar-benar menyetujui isi perjanjian tersebut. Jadi, apa yang dikehendaki oleh pihak yang satu juga dikehendaki oleh pihak yang lainnya secara bebas atau suka rela. Menurut Pasal 1321 KUHPerdata kata sepakat tidak sah apabila diperoleh karena paksaan, kekhilafan dan penipuan.Yang dimaksud paksaan adalah paksaan rohania atau paksaan jiwa, bukan paksaan badan (fisik) misalnya, seseorang diancam atau ditakuttakuti sehingga menyetujui suatu perjanjian. Sedang kekhilafan terjadi apabila salah satu pihak khilaf mengenai barang yang menjadi pokok perjanjian atau mengenai orang dengan siapa diadakan perjanjian sedemikian rupa, sehingga apabila tidak khilaf ia tidak akan memberikan

${ }^{8}$ PNH Simanjuntak, Pokok-pokok Hukum perdata Indonesia, Djambatan ,Jakarta, 2005,hal.334 
persetujuan.Penipuan terjadi apabila suatu pihak dengan sengaja memberikan keterangna palsu atau tidak benar disertai dengan tipu muslihat untuk membujuk memberikan persetujuan.

b) Cakap untuk membuat suatu perjanjian.

Pada dasarnya setiap orang yang sudah dewasa dan sehat pikirannya adalah cakap menurut hukum. Dalam Pasal 1320 KUHPerdata dinyatakan bahwa orang-orang yang dianggap tidak cakap untuk membuat perjanjian adalah :

1) Orang yang belum dewasa;

2) Mereka yang dibawah pengampuan;

3) Orang perempuan dalam halhal yang ditetapkan oleh undang-undang dan semua orang kepada siapa undangundang telah melarang membuat perjanjian-perjanjian tertentu.

Kecakapan harus ada pada subjek yang membuat perjanjian karena ia harus mempertanggungjawabkan

perbuatan-perbuatannya akibat adanya perjanjian tersebut. KUHPerdata memberikan batas usia dewasa yaitu 21 atau sudah kawin, sedangkan UU Perkawinan memberikan batas usia dewasa itu 18 tahun. Orang yang berada di bawah pengampuan adalah orang dewasa yang boros atau yang tidak sehat pikirannya, karenanya orang ini tidak dapat berbuat bebas terhadap kekayaannya sehingga ia berada dibawah pengawasan pengampunya. Dalam Pasal 108 KUHPerdata dinyatakan bahwa wanita yang telah bersuami tidak cakap untuk membuat perjanjian dan karenanya ia harus minta ijin dari suaminya. Namun Mahkamah Agung telah mengeluarkan S.E.M.A No. 3 tahun 1963 yang isinya antara lain agar para hakim tidak lagi menerapkan Pasal 108 KUHPerdata dalam pertimbangan hukumnya. Setelah keluarnya UU Perkawinan tahun 1974 dalam Pasal 31 ayat 1 dengan jelas mengatakan bahwa hak dan kedudukan istri adalah seimbang dengan hak dan kedudukan suami dalam kehidupan rumah tangga dan pergaulan di masyarakat dan dalam ayat 2 dijelaskan bahwa masing-masing pihak berhak untuk melakukan perbuatan hukum.

c) Mengenai hal tertentu

Dalam Pasal 1333 dan Pasal 1334 KUHPerdata dinyatakan bahwa paling tidak objek perjanjian itu harus dapat ditentukan jenisnya, baik benda itu berwujud maupun tidak berwujud. Objek perjanjian dapat berupa benda-benda yang baru akan ada di kemudian hari.

4. Suatu sebab yang halal

Yang dimaksud dengan sebab yang halal adalah maksud dan tujuan perjanjian itu sendiri. Dalam Pasal 1335 KUHPerdata dinyatakan bahwa perjanjian dinyatakan tidak mempunyai kekuatan jika dibuat tanpa sebab atau dibuat berdasarkan sebab yang palsu atau sebab yang terlarang. Perjanjian yang dibuat tanpa sebab, misalnya, jika dibuat suatu perjanjian Novasi atau suatu perjanjian yang tidak ada sebelumnya. Perjanjian yang dibuat berdasarkan sebab yang palsu untuk menutupi sebab yang 
sebenarnya, misalnya, jual beli narkotika untuk sebab pengobatan ternyata untuk pemakaian secara bebas, sedang sebab yang terlarang adalah sebab yang bertentangan dengan undang-undang, ketertiban umum dan kesusilaan. Syarat pertama dan kedua Pasal 1320 KUHPerdata disebut syarat subjektif karena menyangkut orang atau subjek yang membuat perjanjian, bila syarat ini tidak dipenuhi maka perjanjian atas permohonan yang bersangkutan dapat dimintakan pembatalanya kepada hakim yang berlaku sejak putusan hakim memperoleh kekuatan hukum yang tetap. Sedang syarat ketiga dan keempat disebut syarat objektif karena mengenai objek dari perjanjian dan bila salah satu dari syarat tidak dipenuhi, maka perjanjian itu batal demi hukum dimana perjanjian itu dianggap tidak pernah ada sejak semula dan pembatalan ini juga harus dimintakan kepada hakim dimana syarat-syarat yang terdapat pada Pasal 1320 KUHPerdata berlaku juga di dalam perjanjian kredit yang merupakan perjanjian pendahuluan dari penyerahan uang.

Perjanjian yang diatur dalam bagian khusus harus memenuhi syarat-syarat yang diatur dalam Pasal 1338 ayat 1 KUHPerdata. Lembaga perbankan merupakan lembaga yang bertujuan mendukung pelaksanaan pembangunan nasional dalam rangka meningkatkan pemerataan, pertumbuhan ekonomi, dan stabilitas nasional ke arah peningkatan kesejahteraan rakyat banyak. Hal ini ditegaskan dalam Pasal 4 Undang-Undang Perbankan bahwa : "Perbankan Indonesia bertujuan menunjang pelaksanaan pembangunan nasional dalam bentuk kredit dan atau bentuk-bentuk lainnya dalam rangka meningkatkan taraf hidup orang banyak".

Dalam hukum perjanjian, terdapat asas-asas yang perlu diketahui, antara lain sebagai berikut: ${ }^{9}$

a. Asas Kebebasan Berkontrak

Asas kebebasan berkontrak dapat dianalisis dari ketentuan

Pasal 1338 ayat

KUHPerdata yang berbunyi :"

Semua perjanjian yang dibuat secara sah berlaku sebagai undang-undang bagi mereka yang membuatnya".

b. Asas Konsensualisme

Asas konsensualisme dapat disimpulkan dalam Pasal 1320 ayat (1) KUH Perdata yang berbunyi: "Salah satu syarat sahnya perjanjian adalah kesepakatan kedua belah pihak". Hal ini mengandung makna bahwa perjanjian pada umumnya cukup dengan kesepakatan kedua belah pihak.

c. Asas Pacta Sunt Servanda / Kekuatan Mengikat

Asas ini menjelaskan bahwa perjanjian dibuat oleh para pihak secara mengikat atau berlaku sebagai undangundang bagi mereka yang membuatnya. Asas ini memberikan kepastian hukum

9 Wawan Muhwan Hariri, Hukum Perikatan Dilengkapi Hukum Perikatan Dalam Islam, CV Pustaka Setia Bandung, 2011,hal. 136. 
bagi para pihak yang membuatnya.

d. Asas kepribadian

Dalam asas ini, seseorang hanya diperbolehkan mengikatkan diri untuk kepentingannya sendiri dalam suatu perjanjian. Asas ini disimpulkan dalam Pasal 1315 KUH Perdata bahwa dalam suatu perjanjian pada umumnya hanya mengikat para pihak yang mengadakan perjanjian tersebut.

e. Asas Kebiasaan

Suatu perjanjian tidak hanya mengikat apa saja yang secara tegas diatur, tetapi juga hal-hal yang menurut kebiasaan lazim diikuti.

f. Asas Moral

Asas moral ini terlibat dalam perikatan wajar, yaitu suatu perbuatan sukarela dari seseorang tidak dapat menuntut hak baginya untuk menggugat kontraprestasi dari pihak debitur.

g. Asas Itikad Baik

Dalam Pasal 1338 ayat (3) KUH Perdata menyatakan bahwa :"tiap orang dalam membuat suatu perjanjian harus dilakukan dengan itikad baik".

1. Unsur-unsur Dalam Perjanjian

Terdapat 3 unsur dalam perjanjian, yaitu :

a. Unsur Essensialia

Unsur essensialia adalah sesuatu yang harus ada yang merupakan hal pokok sebagai syarat yang tidak boleh diabaikan dan harus dicantumkan dalam suatu perjanjian.Bahwa dalam suatu perjanjian haruslah mengandung suatu ketentuan tentang prestasi-prestasi. Hal ini adalah penting disebabkan hal inilah yang membedakan antara suatu perjnajian dengan perjanjian lainnya. Unsur Essensialia sangat berpengaruh sebab unsur ini digunakan untuk memberikan rumusan, definisi dan pengertian dari suatu perjanjian. Jadi essensi atau isi yang terkandung dari perjanjian tersebut yang mendefinisikan apa bentuk hakekat perjanjian tersebut. Misalnya essensi yang terdapat dalam definisi perjanjian jual beli dengan perjanjian tukar menukar. Maka dari definisi yang dimuat dalam definisi perjanjian tersebutlah yang membedakan antara jual beli dan tukar menukar.

b. Unsur Naturalia

Naturalia adalah ketentuan hukum umum, suatu syarat yang biasanya dicantumkan dalam perjanjian. Unsur-unsur atau hal ini biasanya dijumpai dalam perjanjian-perjanjian tertentu, dianggap ada kecuali dinyatakan sebaliknya.

Merupakan unsur yang wajib dimiliki oleh suatu perjanjian yang menyangkut suatu keadaan yang pasti ada setelah diketahui unsur essensialianya. Jadi terlebih dahulu harus dirumuskan unsur essensialianya baru kemudian dapat dirumuskan unsur naturalianya. Misalnya jual beli unsur naturalianya adalah bahwa si penjual harus bertanggung jawab terhadap kerusakan-kerusakan atau cacat-cacat yang dimiliki oleh barang yang dijualnya. Misalnya membeli sebuah 
televisi baru. Jadi unsur essensialia adalah usnur yang selayaknya atau sepatutnya sudah diketahui oleh masyarakat dan dianggap suatu hal yang lazim

c. Unsur Aksidentalia

Yaitu berbagai hal khusus (particular) yang dinyatakan dalam perjanjian yang disetujui oleh para pihak. Accidentalia artinya bisa ada atau diatur, bisa juga tidak ada, bergantung pada keinginan para pihak, merasa perlu untuk memuat ataukah tidak.

Selain itu aksidentalia adalah unsur pelengkap dalam suatu perjanjian yang merupakan ketentuan-ketentuan yang dapat diatur secara menyimpang oleh para pihak, sesuai dengan kehendak para pihak yang merupakan persyaratan khusus yang ditentukan secara bersamasama oleh para pihak.

Jadi unsur aksidentalia lebih menyangkut mengenai faktor pelengkap dari unsur essensialia dan naturalia, misalnya dalam suatu perjanjian harus ada tempat dimana prestasi dilakukan.

2. Berakhirnya Perjanjian

Pasal 1319 KUHPerdata menetapkan semua perjanjian baik yang mempunyai nama khusus maupun yang tidak dikenal dengan suatu nama tertentu tunduk pada peraturan-peraturan umum. Hal ini menunjukkan bahwa perjanjian kredit merupakan perjanjian yang tidak dikenal di dalam KUHPerdata, namun perjanjian kredit juga harus tunduk pada ketentuan-ketentuan umum yang terdapat di dalam Buku III KUHPerdata. Berakhirnya atau hapusnya perjanjian terdapat pada Pasal 1381 KUHPerdata bahwa hapusnya atau berakhirnya perjanjian disebabkan oleh peristiwa-peristiwa, sebagai berikut : ${ }^{10}$

a. Pembayaran

Pembayaran adalah kewajiban debitur secara sukarela untuk memenuhi perjanjian yang telah diadakan. Adanya pembayaran oleh seorang debitur atau pihak yang berhutang berarti debitur telah melakukan prestasi sesuai perjanjian. Melalui pembayaran yang dilakukan debitur maka perjanjian kredit atau hutang menjadi hapus atau berakhir.

b. Penawaran Pembayaran Tunai diikuti dengan penyimpanan atau penitipan.

Prestasi debitur dengan melakukan pembayaran tunai yang diikuti dengan penitipan dapat mengakhiri atau menghapus perjanjian. Ini adalah suatu cara pembayaran yang harus dilakukan apabila kreditur menolak pembayaran.

c. Novasi/pembaharuan utang

Novasi adalah suatu perjanjian baru yang menghapuskan perjanjian lama dan pada saat yang sama memunculkan perjanjian baru yang menggantikan perjanjian lama.

d. Kompensasi atau perjumpaan utang.

Kompensasi atau perjumpaan hutang adalah suatu cara untuk mengakhiri perjanjian dengan cara memperjumpaan atau memperhitungkan utang piutang antara kreditur dan debitur, yaitu dengan percampuran utang, dan pembebasan utang,

10 PNH Simanjuntak, Pokok-pokok Hukum perdata Indonesia, Djambatan Jakarta, 2005, hal. 323 
e. Pembatalan perjanjian

Suatu perjanjian batal demi hukum maka tidak ada suatu perikatan hukum yang dilahirkan karenanya, dan barang sesuatu yang tidak ada tentu saja tidak bisa hapus, apabila salah satu pihak akan membatalkan perjanjian yang tidak memenuhi syarat subjektif.

f. Daluwarsa

Menurut Pasal 1967 KUH Perdata, maka segala tuntutan hukum baik yang bersifat kebendaan, maupun yang bersifat perorangan hapus karena daluwarsa dengan lewatnya waktu tiga puluh (30) tahun, sedangkan yang menunjuk adanya daluwarsa itu tidak berdasarkan atas suatu hak.

Berakhirnya perjanjian tidak diatur secara tersendiri dalam undang-undang, tetapi hal itu dapat disimpulkan dari beberapa ketentuan yang ada dalam undangundang tersebut. Berakhirnya suatu perjanjian tersebut disebabkan oleh : 11

1) Ditentukan terlebih dahulu oleh para pihak, misalnya dengan menetapkan batas waktu tertentu, maka jika sampai pada batas yang telah ditentukan tersebut, mengakibatkan perjanjian hapus,

2) Undang-undang yang menetapkan batas waktunya suatu perjanjian,

3) Karena terjadinya peristiwa tertentu selama perjanjian dilaksanakan,

4) Salah satu pihak meninggal dunia,

11 Kartini Muljadi dan Gunawan Widjaja. Perikatan yang Lahir dari Perjanjian. Jakarta: PT. Raja Grafindo Persada,2004,hal.43
5) Adanya pernyataan untuk mengakhiri perjanjian yang diadakan oleh salah satu pihak atau pernyataan tersebut sama-sama adanya kesepakatan untuk mengakhiri perjanjian yang diadakan.

6) Putusan hakim yang mengakhiri suatu perjanjian yang diadakan,

7) Telah tercapainya tujuan dari perjanjian yang diadakan oleh para pihak.

Di dalam Pasal 1313 KUH

Perdata, perjanjian dirumuskan sebagai suatu perbuatan dengan mana satu orang atau lebih mengikatkan dirinya tehadap satu orang atau lebih. Kata perjanjian (overrenkomst), yang merupakan salah satu sumber dari perikatan (verbintenis). Perjanjian adalah perbuatan hukum yang berisi penawaran dan penerimaan yang didasarkan kepada kata sepakat antara dua orang atau lebih yang saling berhubungan untuk menimbulkan akibat hukum. Perjanjian merupakan hubungan hukum anatara nasabah dan bank. Nasabah penyimpan adalah nasabah yang menempatkan dananya di bank dalam bentuk simpanan berdasarkan perjanjian bank dengan nasabah. Sedangkan simpanan adalah dana yang dipercayakan oleh masyarakat kepada bank berdasarkan perjanjian penyimpanan dana dalam bentuk giro, deposito, sertifikat deposito, tabungan dan bentuk lainnya yang dipersamakan.

Perjanjian bank dengan nasabah penyimpan disebut perjanjian simpanan. Sebagai perjanjian simpanan terdapat ketentuan dalam Pasal 1319 KUH perdata yang berbunyi : " Semua persetujuan, baik yang mempunyai suatu nama khusus maupun yang tidak terkenal dengan suatu nama tertentu, tunduk pada peraturan-peraturan umum yang termuat di dalam bab ini dan bab yang lalu”. 
Beberapa Pasal yang ada hubungannya dengan perjanjian simpanan, misalnya perjanjian penitipan barang (bewaargeving). Dalam Pasal $1694 \mathrm{KUH}$ Perdata dikatakan bahwa : "Penitipan adalah terjadi, apabila seorang menerima sesuatau barang dari seorang lain, dengan syarat bahwa ia akan menyimpanan dan mengembalikannya dalam wujud aslinya".

Dalam perjanjian simpanan, pihak bank menetapkan persyaratan umum tertentu dalam rekening deposito atau rekening tabungan anatara lain pihak penerima simpanan (bank) dapat mempergunakan uang si penyimpan dan dalam waktu tertentu bank akan memberikan bunga. Ketentuan lain yang dapat dijadikan dasar hubungan anatar bank dan nasabah penyimpan adalah Pemberian Kuasa, dimana pemberian kuasa merupakan suatu persetujuan dengan mana seorang memberikan kekuasanya kepada seseorang lain, yang menerimanya, untuk atas namanya menyelenggarakan suatu urusan. Nasabah penyimpan memberikan kuasanya kepada bank ketika menandatangani rekening deposito atau rekening tabungan atau rekening Koran.

Penandatanganan perjanjian penyimpanan dana menyangkut dua hal, yaitu kesepakatan untuk menyerahkan dana atau uang dari calon nasabah penyimpan dana dan peralihan hak milik dari calon nasabah ke tangan bank. Setelah penandatanganan perjanjian dan uang sudah diserahkan ke bank maka pada saat itu terjadi peralihan hak milik atas uang yang diserahkan. Setelah terjadinya peralihan hak milik maka bank mempunyai kebebasan untuk mengelola dana tersebut untuk modal kegiatan bank.

Hubungan hukum anatara bank dengan nasabah penyimpan mulai terjadi sejak ditandatanganinya kesepakatan tertulis (hubungan kontraktual) antara bank dengan nasabah yang memuat hak dan kewajiban bagi masing-masing pihak. Perjanjian inilah yang menjadi hukum atau undang-undang bagi kedua belah pihak (Pasal 1338 KUH Perdata).

Namun hal yang sering terjadi saat nasabah penyimpan dana bertransaksi dengan pihak bank adalah kebanyakan nasabah tidak mengetahui isi perjanjian yang yang mereka tandatangani. Perjanjian yang seharusnya dibuat berdasarkan kesepakatan antara dua belah pihak sepertinya tidak berlaku karena pihak bank dengan alas an efisiensi telah mempersiapkan klausul baku perjanjian yang tinggal disodorkan dan ditandatangani oleh nasabah dan seringkali dicetak dalam bentuk yang sangat kecil dan terkesan rumit untuk dibaca. Padahal isi atau klausul kontrak pada perjanjian perbankan sangat menentukan hak dan kewajiban yang akan diperoleh dalam melakukan transaksi pada sebuah produk perbankan. Perbankan merupakan lembaga yang menjadi penggerak roda perekonomian modern dan menjadi penentu tingkat kestabilan perekonomian suatu Negara, karena apabila lembaga perbankan tidak berjalan dengan baik, perekonomian menjadi tidak efisien dan pertumbuhan ekonomi tidak akan tercapai. Dalam usaha menghimpun dana dari masyarakat, bank menggunakan cara dengan mengeluarkan produk dan jasa perbankan. Produk tersebut berupa tabungan, giro, deposito, dan jasa perbankan berupa jasa transfer dana, inkaso, bank garansi, letter of credit, waliamanat, dan kliring.

Hubungan antara bank dan nasabah dapat berkembang menjadi hubungan kepercayaan (fiduciare relationship) yang menimbulkan hak dan kewajiban bank lebih besar terhadap nasabahnya. Bank mempunyai kewajiban untuk menjaga dana yang dipercayakan oleh nasabah penyimpan sebaik-baiknya. Sebagai wujud pertanggungjawaban bank terhadap nasabah penyimpan dana, bank harus memperhatikan 4 (empat) pilar 
hubungan antara nasabah penyimpan dana dan bank, yaitu :
1. Kehati-hatian
2. Kesehatan
3. Rahasia bank
4. Kepercayaan.
Penegasan

dalam

menggunakan prinsip kehati-hatian diatur di dalam Pasal 29, ayat (2),(3),(4) UU perbankan yaitu:

Ayat (2): "Bank wajib memelihara tingkat kesehatan bank sesuai dengan ketentuan kecukupan modal, kualitas asset, kualitas manajemen, likuiditas, rentabilitas, solvabilitas dan aspek lain yang berhubungan dengan usaha bank dan wajib melakukan usaha sesuai dengan prinsip kehati-hatian".

Ayat (3) : "Dalam memberikan kredit atau pembiayaan berdasarkan prinsip syariah dan melakukan kegiatan usaha lainnya, bank wajib menempuh cara-cara yang tidak merugikan bank dan kepentingan nasabah yang mempercayakan dananya kepada bank".

Ayat (4) : “ Untuk kepentingan nasabah, bank wajib menyediakan informasi mengenai kemungkinan timbulnya resiko kerugian sehubungan dengan transaksi nasabah yang dilakukan melalui bank".

Usaha pokok perbankan dalam menghimpun dana dari masyarakat dapat berjalan baik semata-mata hanya karena kesediaan masyarakat menyimpan dananya di bank, hal ini dilandasi kepercayaan masyarakat terhadap bank, bahwa dana yang disimpannya dapat kembali pada saat dibutuhkan ditambah bunga sebagai penghasilannya.

Alasan pentingnya kesehatan bagi lembaga keuangan, khususnya perbankan, dalam penciptaan system keuangan yang sehat, antara lain :

1. Keunikan karakteristik perbankan yang rentan terhadap serbuan masyarakat yang menarik dananya secara besar- besaran (bank runs)

sehingga berpotensi merugikan deposan dan penyimpanan dana bank.

2. Penyebaran kerugian di antara bank-banak sangat cepat melalui contagion effect sehingga berpotensi menimbulkan system problem.

3. Proses penyelesaian bankbank bermasalah membutuhkan dana dalam jumlah yang tidak sedikit.

4. Hilangnya kepercayaan masyarakat kepada perbankan sebagai lembaga intermediasi akan menimbulkan tekanantekanan dalam sector keuangan (financial distress).

5. Ketidakstabilan sector keuangan akan berdampak pada kondisi makro ekonomi, khususnya dikaitkan dengan tidak efektifnya transmisi kebijakan moneter.

Perkembangan industri perbankan, terutama produk dan jasa yang semakin kompleks dan beragam dapat meningkatkan eksposur risiko dan profil risiko bank. Sejalan dengan itu pendekatan penilaian secara internasional juga mengarah pada pendekatan pengawasan berdasarkan risiko. Peningkatan ekspour risiko dan profil risiko serta penerapan pendekatan pengawasan berdasarkan risiko tersebut selanjutnya akan mempengaruhi penilaian tingkat kesehatan bank.

Menjaga rahasia bank merupakan tanggungjawab bank terhadap penyimpan dana. Nasabah yang akan membuka rekening di bank wajib mengisi data-data yang ditanyakan dan mengisi formulir secara lengkap, jelas, dan benar 
antara lain : nama nasabah, alamat, tanggal lahir, nomor telepon, nama ibu kandung dan keterangan lain yang merupakan identitas pribadi dan lazim diberikan nasabah pada bank dalam pemanfaatan produk bank, disertai penunjukan kartu identitas yang masih berlaku seperti Kartu Tanda Penduduk. Menurut pasal 1 UU Perbankan, data nasabah yang ditulis dan diserahkan fotokopinya merupakan termasuk rahasia bank. Dengan demikian menjadi kewajiban bank untuk melindungi data nasabah melalui pengaturan rahasia bank. Kewajiban merahasiakan data nasabah merupakan kewajiban yang diatur dalam peraturan perundang-undangan yang bersifat memaksa.

Penentuan hal-hal yang

termasuk kategori rahasia bank harus berpijak pada :

1. Kelaziman operasional perbankan Operasional perbankan yang utama adalah menghimpun dana masyarakat serta memberikan kredit. Dalam hal ini bank mengadakan pencatatan-pencatatan data-data, dan informasi jalannya usaha yang dilakukan serta dalam hubungannya dengan nasabahnya.Hal-hal yang harus dirahasiakan bank meliputi : pemberian pelayanan, dan jasa dalam lalu lintas uang, baik dalam maupun luar negeri, pendiskontoan, dan jual beli surat berharga dan pemberian kredit.

2. Apakah pembocoran/ pembukaan informasi akan merugikan pemilik informasi (nasabah) atau menguntungkan pihak lain.

3. Pihak pemilik informasi (nasabah) harus yakin secara wajar bahwa informasi itu benar-benar belum diketahui masyarakat luas.

Pengecualian dalam hal rahasia bank tercantum dalam Pasal 40 ayat (1) Undang-undang Nomor 10Tahun 1998 tentang Perbankan, yang menyebutkan bahwa bank wajib merahasiakan keterangan mengenai nasabah penyimpan dan simpanannya. Keterangan mengenai nasabah penyimpan dan simpanannya itu boleh diungkapkan dalam hal-hal sebagai berikut :

1. Untuk kepentingan Perpajakan

Pembukaan rahasia bank untuk kepentingan perpajakan diatur dalam ketentuan Pasal 41 ayat (1) UU Perbankan yang menentukan bahwa : “ Untuk kepentingan perpajakan, Pimpinan Bank Indonesia atas permintaan Menteri Keuangan berwenang untuk mengeluarkan perintah tertulis kepada bank agar memberikan keterangan dan memperlihatkan buktibukti tertulis serta suratsurat mengenai keadaan keuangan nasabah penyimpan tertentu kepada pejabat pajak".

2. Untuk kepentingan Piutang Bank (Pasal 41 A)

3. Untuk Kepentingan Pidana (Pasal 42)

4. Untuk Kepentingan Pemeriksaan Peradilan Perdata (Pasal 43)

5. Untuk Kepentingan Tukar Menukar Informasi Antar Bank (Pasal 44)

6. Untuk Kepentingan Pihak Lain yang ditunjuk Nasabah (Pasal 44(1)

7. Pengecualaian Rahasia Bank untuk kepentingan Peradilan mengenai Harta Bersama dalam Perceraian.

\section{P E N U T U P}

Berdasarkan uraian pembahasan, maka penulis dapat 
menarik kesimpulan bahwa bentuk perjanjian penyimpanan dana antara nasabah dan pihak bank disebut perjanjian simpanan. Sebagai perjanjian simpanan terdapat ketentuan dalam Pasal 1319 KUH perdata yang berbunyi : “ Semua persetujuan, baik yang mempunyai suatu nama khusus maupun yang tidak terkenal dengan suatu nama tertentu, tunduk pada peraturan-peraturan umum yang termuat di dalam bab ini dan bab yang lalu". Dalam perjanjian simpanan, pihak bank menetapkan persyaratan umum tertentu dalam rekening deposito atau rekening tabungan anatara lain pihak penerima simpanan (bank) dapat mempergunakan uang si penyimpan dan dalam waktu tertentu bank akan memberikan bunga. Ketentuan lain yang dapat dijadikan dasar hubungan anatar bank dan nasabah penyimpan adalah Pemberian Kuasa. Nasabah penyimpan memberikan kuasanya kepada bank ketika menandatangani rekening deposito atau rekening tabungan atau rekening Koran. Penandatanganan perjanjian penyimpanan dana menyangkut dua hal, yaitu kesepakatan untuk menyerahkan dana atau uang dari calon nasabah penyimpan dana dan peralihan hak milik dari calon nasabah ke tangan bank. Setelah penandatanganan perjanjian dan uang sudah diserahkan ke bank maka pada saat itu terjadi peralihan hak milik atas uang yang diserahkan. Setelah terjadinya peralihan hak milik maka bank mempunyai kebebasan untuk mengelola dana tersebut untuk modal kegiatan bank. Hubungan hukum anatara bank dengan nasabah penyimpan mulai terjadi sejak ditandatanganinya kesepakatan tertulis (hubungan kontraktual) antara bank dengan nasabah yang memuat hak dan kewajiban bagi masing-masing pihak. Perjanjian inilah yang menjadi hukum atau undang-undang bagi kedua belah pihak (Pasal 1338 KUH Perdata).

1. Bank mempunyai kewajiban untuk menjaga dana yang dipercayakan oleh nasabah penyimpan sebaikbaiknya. Sebagai wujud pertanggungjawaban bank terhadap nasabah penyimpan dana, bank harus memperhatikan 4 (empat) pilar hubungan antara nasabah penyimpan dana dan bank, yaitu :
a. Kehati-hatian
b. Kesehatan
c. Rahasia bank
d. Kepercayaan.

Menjaga rahasia bank merupakan tanggungjawab bank terhadap penyimpan dana. Nasabah yang akan membuka rekening di bank wajib mengisi data-data yang ditanyakan dan mengisi formulir secara lengkap, jelas, dan benar antara lain : nama nasabah, alamat, tanggal lahir, nomor telepon, nama ibu kandung dan keterangan lain yang merupakan identitas pribadi dan lazim diberikan nasabah pada bank dalam pemanfaatan produk bank, disertai penunjukan kartu identitas yang masih berlaku seperti Kartu Tanda Penduduk. Menurut pasal 1 UU Perbankan, data nasabah yang ditulis dan diserahkan fotokopinya merupakan termasuk rahasia bank. Dengan demikian menjadi kewajiban bank untuk melindungi data nasabah melalui pengaturan rahasia bank. Kewajiban merahasiakan data nasabah merupakan kewajiban yang diatur dalam peraturan perundang-undangan yang bersifat memaksa.

Keterangan mengenai nasabah penyimpan dan simpanannya itu 
boleh diungkapkan dalam hal-hal sebagai berikut :

1. Untuk kepentingan Perpajakan (Pasal 41 ayat (1))

2. Untuk kepentingan Piutang Bank (Pasal 41 A)

3. Untuk Kepentingan Pidana (Pasal 42)

4. Untuk Kepentingan Pemeriksaan Peradilan Perdata (Pasal 43)

5. Untuk Kepentingan Tukar Menukar Informasi Antar Bank (Pasal 44)

6. Untuk Kepentingan Pihak Lain yang ditunjuk Nasabah (Pasal 44(1)

7. Pengecualaian Rahasia Bank untuk kepentingan Peradilan mengenai Harta Bersama dalam Perceraian.

\section{DAFTAR PUSTAKA}

Abdulkadir Muhammad, dan Rilda Murniati , Segi Hukum Lembaga Keuangan Dan pembiayaan, Bandung, Citra Aditya Bakti, 2000

Ahmadi Miru \& Sutarman Yodo, Hukum Perlindungan Konsumen, Raja Grafindo Persada, Jakarta,2011

Gunarto Suhardi, Usaha Perbankan Dalam Perspektif Hukum, Yogyakarta, Kanisius, 2003

Abdul kadir Muhammad, Hukum dan Penelitian Hukum, PT. Citra Aditya Bakti, Bandung, 2004.

Budisantoso, $\mathrm{T}$ dan Sigit,. Bank dan Lembaga Keuangan Lain. Edisi 2 Salemba Empat.Jakarta, 2006

Hasibuan, Melayu SP. Dasar-dasar Perbankan.PT. Bumi Aksara. Jakarta 2005

HR Daeng Naja, Hukum Kredit dan Bank Garansi, PT.Citra Aditya Bakti,Bandung, 2005
H.M Hazniel Harun, Aspek-aspek Hukum Perdata Dalam Pemberian KreditPerbankan, Ind-HillCo, Jakarta, 1994

Joni Emirzon, Hukum Perbankan Indonesia, Literata, Jakarta, 2007

Johannes Ibrahim. Bank Sebagai Intermediasi Dalamm Hukum Positif CV. Utomo,Bandung, 2004

Kasmir. $\quad$ S.E., M.M, Dasar-Dasar Perbankan PT. Raja Grafindo Persada ,Jakarta 2002

Kartini Muljadi dan Gunawan Widjaja. Perikatan yang Lahir dari Perjanjian. PT. Raja Grafindo Persada,Jakarta, 2004

Muhammad Djumhana, Hukum Perbankan Indonesia, PT. Citra Aditya Bakti, Bandung, 2000.

PNH Simanjuntak, Pokok-pokok Hukum Perdata Indonesia, Djambatan ,Jakarta, 2000

Rani Sri Agustina, Rahasia Bank, Cv Keni Media, Bandung, 2016

R. Subekti dan R. Tjitrosudibio, Hukum Perjanjian, Internusa, Jakarta, 1987

Rachmadi Usman, Hukum Jaminan Keperdataan.Sinar Grafika,Jakarta, 2008 Sutarno, Aspek-Aspek Hukum Perkreditan Pada Bank.Alfabeta,Bandung, 2005

Wawan Muhwan Hariri, Hukum Perikatan Dilengkapi Hukum Perikatan Dalam Islam, CV Pustaka Setia Bandung, 2011

Widjanarto, Hukum dan Ketentuan Perbankan Indonesia, PT. Pustaka Utama Grafiti, Jakarta, 2003. 